\author{
Д.О. Никулин
}

Офицер и инструкция: роль личного фактора в подготовке маршевых рот Первой мировой войны (Омский военный округ)

DOI: $10.31518 / 2618-9100-2018-2-11$

УДК 94(47).083

Выходные данные для цитирования:

Никулин Д.О. Офицер и инструкция: роль личного фактора в подготовке маршевых рот Первой мировой войны (Омский военный округ) // Исторический курьер. 2018. № 2. Статья 11. URL: http://istkurier.ru/data/2018/ISTKURIER-2018-2-11pdf
Daniil Nikulin *

\section{Officer and Instruction: the Role of Personal Factor in the Training of Marching Companies of the World War I (Omsk Military District)}

\author{
DOI: $10.31518 / 2618-9100-2018-2-11$
}

How to cite:

Nikulin Daniil O. Officer and instruction: the role of personal factor in the training of marching companies of the World War I (Omsk military district) // Historical courier, 2018, \# 2. Article 11. [Available online:]

http://istkurier.ru/data/2018/ISTKURIER-2018-2-11.pdf

Abstract: This article is based on materials of inspections of the marching companies intended for departure to the battle-front that had completed a course of training in the depot battalions of the Omsk military district. As can be seen from the orders to the battalions, brigades and the military district, the marching companies varied significantly in terms of their qualification. The aim of the article is to check the presumption that the differences depended upon the officers' personal qualities and their views on the training methods. The facts discovered by the author let confirm that the majority of commanders possessed a certain degree of freedom within the limits of official instructions. Although the training program was partly determined by the "The regulation on infantry training", main officers were in a position to alter certain points of instructions and regulations. Making timetables for exercises in their units, the commanders would take into consideration their own priorities concerning personnel training. Some of them paid more attention to shooting, others to formation training, etc. Some commanders tried to introduce novelties in respect to the experience of the Russo-Japanese war and World War I; meanwhile the others would exercise old methods. It was only partly that the state of affairs depended upon the main officers' views because junior commanders (company officers) were not always active enough and successful enough in fulfilling the instructions received.

Keywords: World War I; Omsk military district; depot battalions; training; inspection.

The article has been received by the editor on 02.10.2018.

Full text of the article in Russian and references in English are available below.

Аннотация: Статья основана на материалах проверок предназначенных к отправке на фронт маршевых рот, прошедших курс обучения в запасных батальонах Омского военного округа. Как видно из приказов по батальонам, бригадам и по военному округу, уровень подготовки рот существенно разнился. Цель статьи - проверить предположение о зависимости этих различий от личных качеств офицеров и их взглядов на методы организации учёбы. Установленные автором факты позволяют утверждать, что большинство командиров обладало известным уровнем свободы в рамках официальных инструкций. Хотя программа обучения отчасти определялась "Положением об обучении пехоты", командующие соединениями обладали возможностью изменять отдельные пункты

\footnotetext{
* Никулин Даниил Олегович, младший научный сотрудник Института истории СО РАН (г. Новосибирск, Россия), e-mail: nikdanya@mail.ru

Nikulin Daniil Olegovich, junior researcher, Institute of History of the Siberian Branch of the Russian Academy of Sciences (Novosibirsk, Russia), e-mail: nikdanya@mail.ru
} 
официальных инструкций и положений. Составляя расписания занятий в подчинённых им частях, командиры учитывали свои личные приоритеты в подготовке личного состава: одни больше внимания уделяли стрельбе, другие - строевой подготовке, и так далее. В то время как одни стремились вводить новшества с учётом опыта Русско-японской и начавшейся Первой мировой войны, другие продолжали при подготовке солдат следовать старым методам. Взгляды вышестоящих командиров лишь отчасти определяли положение дел, так как нижестоящие офицеры (командиры рот) не всегда достаточно деятельно и успешно воплощали данные им указания.

Ключевые слова: Первая мировая война; Омский военный округ, запасные батальоны, боевая подготовка, маршевые роты.

Первая Мировая война 1914-1918 гг. явилась одним из важнейших событий ХХ века, внеся, помимо прочих глобальных изменений, значительный вклад в развитие военного дела. Командирам запасных частей приходилось на ходу вносить коррективы в методику подготовки, которая, хоть и была модернизирована благодаря опыту Русско-японской войны 1904-1905 гг., оставалась ещё во многом устаревшей. Модернизация, имевшая место в годы Первой мировой войны, явилась продолжением бурного развития военного дела второй половины XIX в., темы, отмеченной многими военными историками. В частности, еще А. А. Свечин прослеживал изменения, имевшие место в это время, на примере как русской армии, так и армий её противников ${ }^{1}$. Позднее Л. Г. Бескровный отмечал, что "сокращенные сроки службы обусловили необходимость сжать первоначальный период личной подготовки и усилить совместную отработку полученных навыков в подразделениях"; в то же время "в армию приходило довольно значительное число новобранцев, нуждавшихся в освоении грамоты и счета, без чего нельзя было усвоить основные положения уставов и инструкций"2.

В то же время имелись и негативные тенденции в боевой подготовке. В качестве таковых П. А. Зайончковский выделяет две: 1) "плац-парадную", рассчитанную на показной эффект, и 2) "драгомировскую", предполагающую обучение войск лишь тому, что необходимо на войне. Вторая тенденция на первый взгляд кажется разумной, в историографии существуют высокие оценки её главного идеолога - генерала М. И. Драгомирова. Его большим недостатком считается, однако, то, что он недооценивал важность стремительно развивавшейся в те годы военной техники, придавал слишком большое значение штыковым атакам ${ }^{3}$.

О том же говорил военный историк из эмигрантских кругов А. А. Керсновский. В отличие от Зайончковского, он выделял три направления в военной мысли того периода. Первое соответствует "плац-парадной" тенденции, выделенной последним; представителей второй он именует "младотурками", называя таких деятелей, как генерал Д. Г. Щербачев, полковники Н. Н. Головин и А. А. Свечин. "Младотурки" стремились модернизировать отечественное военное дело с опорой на зарубежный, в первую очередь французский и немецкий, опыт. Третья выделяемая А. А. Керсновским группа - «классики» - были сторонниками возрождения старых традиций русского военного искусства. Керсновский высоко оценивал сделанные после Русско-японской войны изменения в подготовке войск, но лишь среди мелких подразделений - рот, эскадронов и батарей. Как он писал, "наши отлично применявшиеся к местности взводы, великолепно стрелявшие роты и проявлявшие частный почин батальоны оказывались заключенными в вялые дивизии, неуклюжие корпуса и рыхлые армии"4. Весьма жёстко он критиковал генерала М. И. Драгомирова, его

\footnotetext{
${ }^{1}$ Свечин А. А. Эволюция военного искусства. Том II. - М.-Л.: Военгиз, 1928. 619 с.

${ }^{2}$ Бескровный Л. Г. Армия и флот России в начале ХХ в.: Очерки военно-экономического потенциала Институт истории АН СССР. М.: Наука, 1986. С. 27.

3 Зайончковский П.А. Самодержавие и русская армия на рубеже XIX-XX столетий. М.: Мысль, 1973. C. 253-262.

${ }^{4}$ Керсновский А. А. История русской армии в 4-х томах. Т. 3. М.: Голос, 1994. С. 149.
} 
пренебрежительное отношение к техническим новшествам и "сохранности бойцов". Кроме того, Керсновский отмечал (и это наиболее ценно для нас), что "в различных округах войска были обучены по-разному, в зависимости от взглядов командующих войсками. В одном и том же округе система обучения менялась с каждым новым командующим"1, в зависимости принадлежности последнего к тому или иному роду войск. А. А. Строков отмечал усиление индивидуального аспекта в подготовке личного состава, развитие активности и инициативы в действиях командиров частей и подразделений. Он относил эти положительные изменения к влиянию опыта Русско-японской войны, способствовавшему также росту индивидуальности бойца, улучшению боевой подготовки офицеров ${ }^{2}$.

Похожие замечания высказывал профессор стратегии Колледжа Генерального штаба и командного состава Армии США Брюс Меннинг, тщательно изучивший развитие военного искусства в России в пореформенную эпоху, подробно описавший болезненный и долгий переход к переменам в русской военной доктрине в связи со стремительным развитием вооружений. Хотя большинство его замечаний касаются тактики и стратегии, они актуальны и для вопросов подготовки личного состава ${ }^{3}$. О достаточно обширной теме изменений в армии после милютинской реформы так или иначе рассказывается во многих работах зарубежных авторов, посвященных разным аспектам вопроса: вооружениям, ресурсам, развитию стратегии и тактики ${ }^{4}$. В качестве предыстории проблема предвоенного развития затрагивается в работах, посвященных непосредственно Первой мировой войне и Февральской революции 5 . Были сделаны выводы о снижении влияния армии на общество, уменьшении военного бюджета, важности борьбы военного министерства с министерством финансов. Существует также ряд публикаций, посвященных развитию военного дела и новшествам Первой мировой войны - танкам, развитию маневрирования, окопного дела и пр. ${ }^{6}$. До сих пор авторитетной остается книга Нормана Стоуна о Восточном фронте Первой мировой войны; в ней он отмечал, кроме всего прочего изменения, имевшие место после Русско-японской войны, несмотря на определённый консерватизм русского командования ${ }^{7}$. Важную роль индивидуального начала во взглядах армейского руководства отмечал военный атташе Великобритании генерал А. Нокс, кратко затронувший и систему запасных батальонов $^{8}$. Все эти авторы отмечали консервативность военной администрации, замедлявшей любые возможные реформы, приоритет в кадровых вопросах связей и старшинства над талантами и умениями, низкую оплачиваемость и малую престижность офицерской профессии, преобладание в армии малограмотного крестьянства и слабость экономической базы.

\footnotetext{
1 Там же. С. 28.

${ }^{2}$ Строков А. А. Вооруженные силы и военное искусство в Первой мировой войне. М.: Воениздат, 1974. C. $166-167$.

${ }^{3}$ Меннинг, Брюс У. Пуля и штык. Армия Российской империи, 1861-1914. М.: Модест Колеров, 2015.424 с.

${ }^{4}$ См: Pintner, Walter M. The Burden of Defense in Imperial Russia, 1725-1914. // The Russian Review, vol. 43, 1984, pp. 231-259. Transformation in Russian and Soviet Military History: Proceedings of the 12th Military Symposium United States Air Force Academy / ed. by Carl W. Reddel. United States Govt Printing Office, 1986. 405 p. The Military History of Tsarist Russia. / ed. by Robin D. S. Higham, Frederick W Kagan. Palgrave, 2002.266 p. Reforming the Tsar's Army: Military Innovation in Imperial Russia from Peter the Great to the Revolution. / ed. by David Schimmelpenninck van der Oye, Bruce W. Menning. Cambridge: Cambridge University Press, 2004.376 p.

${ }^{5}$ Wildman, Allan K. The End of the Russian Imperial Army: The Old Army and the Soldiers' Revolt (March-April, 1917). Vol. 1. Princeton: Princeton University Press, 1980. 434 p.

${ }^{6}$ Zabecki, David T. Military Developments of World War I. // 1914-1918 online International Encyclopedia of the First World War. / ed. by Ute Daniel, Peter Gatrell, Oliver Janz, Heather Jones, Jennifer Keene, Alan Kramer, and Bill Nasson, issued by Freie Universität Berlin, Berlin 2015-05-07. [Электронный pecypc] URL: https://encyclopedia.1914-1918-online.net/article/military_developments_of_world_war_i (Дата обращения: 01.10.2018). Travers, Tim. Could the Tanks of 1918 Have Been War-Winners for the British Expeditionary Force? // Journal of Contemporary History. Vol. 27, No. 3 (Jul., 1992), pp. 389-406.

${ }^{7}$ Stone, Norman. The Eastern Front, 1914-1917. London: Penguin, 1998. 348 p.

${ }^{8}$ Knox, A. W. F. With the Russian Army 1914-1917, being chiefly extracts from the diary of a military attache. V. 1. London: Hutchinson \& co., 1921. 368 p.
} 
В то же время непосредственно подготовка личного состава освещена не так подробно. Стоит упомянуть публикацию преподавателя Бирмингемского университета, автора монографий по истории Первой мировой войны Дж. Боффа, посвященную подготовке солдат британской, германской и французской армий в годы Первой Мировой войны. Становится понятно, что их срок обучения был более стандартизованным, чем у солдат русской армии, в то время как программа подготовки разнилась в зависимости от того, когда и куда они попали на службу. Как и в русской армии, новые пополнения часто доучивались в расположении части вблизи от линии фронта. Часто их боевые качества критиковали бывалые солдаты из довоенных кадров ${ }^{1}$.

С началом войны в 1914 г. кадровые сибирские соединения мирного времени были отправлены на фронт, а вместо них в Омском военном округе (ОмВО) были образованы 3-я и 4-я, позднее - 5-я Сибирские стрелковые запасные бригады. В интересующие нас три бригады входили 20 запасных батальонов, впоследствии, в апреле 1916 г., развернутых в полки. Именно эти батальоны занимались подготовкой и отправкой на фронт так называемых очередных рот пополнения, или маршевых рот, как они начинали называться при отправке на фронт. Процесс этот регламентировался "Положением об обучении пехоты", утвержденным в 1911 г.

Согласно "Положению", по окончании двухмесячного срока обучения командир батальона должен был проверять степень подготовки молодых солдат, не нарушая хода занятий, и доносил о результатах проверки командиру, после чего роту проверял командир полка или комиссия под его руководством. На практике в именно таком виде проверки были реализованы только после переименования батальонов в полки, что было вызвано фактическим отсутствием до этого в структуре округа офицеров, аналогичных упомянутым командирам батальонов - называвшиеся так офицеры фактически были ближе к командирам полков, да и наделены были именно правами таковых, согласно "Положению о запасных батальонах пехоты"2.

"Положение об обучении пехоты" давало следующие рекомендации при проверке готовности:

а) Проверять все отделы обучения. Не увлекаться каким-то одним, учитывать степень значения отдела в общей боевой подготовке войск.

б) Требования основывать на уставах, наставлениях, инструкциях.

в) Добиваться от солдата ясного понимания материала, а не просто повторения пройденного.

г) Строевую и стрелковую подготовку проверять в полном походном снаряжении, обращая внимание на одиночную выправку, подготовку к действию в рассыпном строю, отчетливое исполнение команд, дисциплину строя, правильную изготовку, быстрое заряжание, правильную прикладку, прицеливание и спуск курка.

д) По гимнастике проверялась одиночная подготовка; начальник, производивший смотр, назначал некоторое число упражнений.

е) Подготовка к полевой службе проверялась на местности, обращая внимание на сознательное усвоение молодыми солдатами обязанности по несению службы дозоров и на сторожевом посту ${ }^{3}$.

За эффективностью подготовки в первую очередь следили командиры батальонов (полков), а ответственность за неё несли офицеры или унтер-офицеры кадровой роты, при которой проходили подготовку солдаты маршевой роты ${ }^{4}$. В случае провала ротный командир мог быть снят с должности, и это было наиболее жёстким наказанием, которому мог на

\footnotetext{
${ }^{1}$ Boff, Jonathan. Training to be soldier. [Электронный pecypc] URL: https://www.bl.uk/world-warone/articles/training-to-be-a-soldier (Дата обращения: 01.10.2018).

${ }^{2}$ Государственный архив Новосибирской области (далее - ГАНО). Ф. Д-136. Оп. 1. Д. 4. Л. 8 об.

${ }^{3}$ Положение об обучении пехоты: Высочайше утверждено 22 декабря 1911 г. СПб.: Военная типография, 1911. $-111 \mathrm{c}$.

${ }^{4}$ ГАНО. Ф. Д-132. Оп. 1. Д. 8. Л. 87, 151 об.
} 
практике подвергнуться офицер запасного батальона. В случае же хорошей подготовки роты командир и личный состав получали благодарность. Возможные недоработки офицеров и учителей из нижних чинов были весьма разнообразны; так, при проверке 50-й очередной роты пополнения 38-го запасного батальона выяснилось, что командир роты не знал команд для открытия огня и перемещения цепи; солдатам не объяснили, что такое кавалерия, артиллерия. За эти и другие недостатки командир - подпоручик Шишенков - был снят с должности. Случалось и так, что в результате отсутствия или уменьшения интенсивности занятий очередные роты пополнения деградировали - так, командир того же батальона отмечал, что к концу декабря 1915 г. 37-я рота пополнения продемонстрировала гораздо более слабые показатели, чем во время предыдущей проверки ${ }^{1}$. Несколько противоречивое требование "Положения" не увлекаться какими-то конкретными отделами обучения, но учитывать значение отделов в общей боевой подготовке на практике привело к вполне справедливому особенному упору на стрелковую подготовку. Стрельба признавалась, в частности, более важным аспектом подготовки, чем строевая подготовка, т.к. «строю можно учить и при переходах» ${ }^{2}$. Это может быть свидетельством отмеченной А. А. Керсновским тенденции уделять особенное внимание стрельбе в результате опыта, извлеченного из боевых действий Русско-японской войны. Однако опыт этот учитывался не полностью: значительно медленнее развивалась подготовка самоокапыванию - 18 ноября 1915 г. в приказании по ОмВО регламентировалась сапёрная подготовка, в рамках которой преподавалось окопное дело, а 24 марта 1916 г. был составлен еще один приказ, во многом повторявший положения предыдущего ${ }^{3}$.

Следующей после командиров батальонов (полков) инстанцией были командующие бригадами; здесь в большей степени свою роль играл индивидуальный фактор среди командиров. 20 января 1915 г. командующий 3-й Сибирской стрелковой запасной бригадой генерал-лейтенант Н. И. Тимченко-Рубан в приказе по бригаде сетовал, что "старая, мирная школа, школа сомкнутых строев, ломка фронтов, ружейных приемов"4 все еще доминирует. Он утверждал, что нужно вырабатывать сознательного бойца. Так, его критике подверглись методы подготовки пополнения в 7-й роте 28-го запасного батальона: "В строю стояли ратники лишь на второй неделе своего прибытия в б[атальо]н и усердно практиковались взводным строевым учением и ломкою фронта. Солдат еще и стоять не умеет, не знает, где у него правая и левая нога, тужится одновременно выносить на ходу и правую ногу и правую руку одновременно, смотрит куда-то в поле при обхождении начальника по фронту, а его уже обучают взводному ученью" ${ }^{2}$. Командующий бригадой требовал отменить взводное учение, ограничиваясь одиночной выправкой, в крайнем случае - отделенным обучением.

В ходе проверок в ротах 3-й бригады в апреле 1915 - марте 1916 гг. командующим был отмечен высокий уровень подготовки. Проверялись самоокапывание, выправка, знание уставов и количество пройденных упражнений стрельбы. Особое внимание уделялось тому, чтобы роты были разбиты на партии с учителями. Ввиду хорошей функциональной подготовки, но некоторой робости и недостаточного знания теории большое внимание уделялось интеллектуальному развитию солдат, рекомендовалось задавать им многочисленные вопросы по полевой службе, обязанностям и познаниям стрелка, «шевелить их мозговую деятельность» ${ }^{6}$. В ходе проверок была запрещено обучение приемам боя штыком и прикладом в составе шеренги - в условиях краткости курса подготовки предпочтение было отдано соответствующим одиночным занятиям как более сложным и универсальным. Было отдано распоряжение ежедневно составлять программу занятий на

\footnotetext{
${ }^{1}$ Там же. Д. 7. Л. 41 об.

${ }^{2}$ Там же. Д. 1. Л. 202

3 Приказы по войскам Омского военного округа. Приказания. 1915. № 251; Исторический архив Омской области (далее - ИАОО). Ф. 54. Оп. 1. Д. 107. Л. 136-137.

${ }^{4}$ Российский государственный военно-исторический архив далее - РГВИА). Ф. 15953. Оп. 1. Д. 1. Л. 68 об.

5 Там же.

${ }^{6}$ РГВИА. Ф. 15954. Оп. 1. Д. 1. Л. 21 об.
} 
следующий день, чтобы сделать подготовку более гибкой и избежать недоразумений с нехваткой места на плацу, плохой погодой и пр.

Взгляд командующего бригадой на строевую подготовку как не слишком важную был, однако, не повсеместным; так, по прибытии в действующий 19-й стрелковый полк 21-я маршевая рота 37-го Сибирского стрелкового запасного батальона была охарактеризована как слабо обученная сомкнутому строю. Очевидно, временный командир этого полка, полковник Попов, продолжал уделять этому строю большое внимание ${ }^{1}$. Даже в прифронтовых частях взгляды были разными: так, офицер управления инспектора запасных войск Западного фронта полковник В. В. Лучинин отделял строевую подготовку от боевой, отдавая последней приоритет и включая в неё полевую службу и рассыпной строй, другие же офицеры в общей характеристике готовности роты ставили сомкнутый строй наравне с рассыпным. Сообщения из прифронтовых частей позволяют судить о подобных же взглядах на подготовку в батальонах ОмВО: так, согласно сообщению из 17-го стрелкового полка от 29 октября 1915 г., 4-я маршевая рота 37-го Сибирского стрелкового запасного батальона и 8-я маршевая рота 28-го Сибирского стрелкового запасного батальона много занимались сомкнутым строем в ущерб рассыпному. Интересно, что эти батальоны входили в состав 3-й запасной бригады генерала Тимченко-Рубана. Очевидно, даже спустя более полугода после своих критических замечаний он так и не сумел окончательно побороть в своей бригаде чрезмерное обучение сомкнутому строю. Причиной этого стоит, по-видимому, считать ошибки ротных командиров, так как в 37-м запасном батальоне были как хорошо, так и плохо обученные рассыпному строю маршевые роты (это не позволяет считать, будто указания командующего бригадой не были исполнены из-за особых взглядов командира батальона). Однако не только в 3-й запасной бригаде сомкнутый строй оставался популярным - в том же 17-м стрелковом полку отмечали, что 26-я маршевая рота 33-го запасного батальона, входившего 4-ю Сибирскую стрелковую запасную бригаду, была "не твердо" обучена рассыпному строю, но "очень хорошо" - сомкнутому².

Несколько иные приоритеты были у командующего 5-й Сибирской стрелковой запасной бригадой полковника В.А. Бирона. В октябре - декабре 1916 г., уже после переформирования батальонов в полки, он устроил несколько смотров 26-ти уходящим на фронт маршевым ротам, готовившимся от 4 до 8 недель. Особое внимание уделялось выправке, знанию и применению на практике уставов, отданию чести, штыковому бою. Особое внимание полковник Бирон обращал на знание полевого устава, бывшее слабым местом большинства рот. Было выделено несколько особенно слабых рот. Так, была отмечена слабая дисциплина 140-й маршевой роты 18-го Сибирского стрелкового запасного полка, неправильное проведение стрельб. Грубые ошибки были допущены при практическом применении полевого устава. Старший унтер-офицер не знал о дозорах для поверки караулов и вместо часового с подчаском выставил "наблюдателей", на вопрос "зачем вы поставлены?" ответивших: "Не можем знать. Нас поставил взводный". Часовому была поставлена задача: "На возу с сеном, который едет прямо на тебя, за бабой сидят три неприятельских разведчика. Распоряжайся". Часовой передал эту информацию через подчаска в полевой караул, начальник которого просигнализировал папахой на штыке на заставу, чем не мог не выдать свою позицию условному противнику. "На заставе произошло какое-то движение, потом все успокоилось. Воз с сеном беспрепятственно проехал мимо часового, начальника полевого караула и заставы. Часовой продолжал безучастно лежать". Начальник полевого караула не понял донесения. Начальник заставы решил задержать разведчиков, когда они уже проехали бы заставу. Согласно «Уставу полевой службы» от 1901 г., а также «Полевому уставу для унтер-офицеров» от 1913 г., начальник полевого караула должен был послать на заставу донесение, а часовой обязан был остановить нарушителей при подходе их на дистанцию ближе 50 шагов, в случае необходимости - применить оружие. Застава же по

\footnotetext{
${ }^{1}$ ИАОО. Ф. 67. Оп. 2. Д. 3208. Л. 5об.

${ }^{2}$ ИАОО. Ф. 67. Оп. 2. Д. 3208. Л. 14об.
} 
получении донесения от начальника полевого караула должна была быть приведена в готовность.

141-я маршевая рота того же полка, по замечаниями В.А. Бирона, имела слабую дисциплину, не знала общих сведений, обязательных для рядового, не умела стрелять, не знала содержания полевого устава и не умела применять его на практике. Во время наступления в рассыпном строю рота потеряла направление, командир не смог поддерживать связь со взводными, совершались перебежки большими частями в непосредственной близости от условного противника.

76-я маршевая рота 38-го Сибирского стрелкового запасного полка также показала слабое умение применять на практике Полевой устав. Так, застава шла сомкнутым строем по видимой "противником" поляне, часовой не зарядил винтовку и не знал, где враг. Отмечался унылый вид солдат 75-й маршевой роты того же полка, страх их перед офицерами, незнание ими сведений, обязательных для рядового, малоосмысленность ответов, слабое знание Полевого устава, плохое построение рассыпным строем с тесными цепями и одновременными перебежками сразу нескольких звеньев. Кроме того, солдаты не умели отдавать честь, а также совершенно не владели самоокапыванием.

По итогам состоявшихся проверок полковник В.А. Бирон отменил в своей бригаде смотры командирами батальонов, т.к. они должны были лично присутствовать при обучении маршевых рот. Смотры же командирами полков командующий распорядился передвинуть с последней недели обучения на четвертую-пятую, с тем чтобы в конце обучения самому проверять роты; ранее же недостатки, замечавшиеся командирами полков, до смотра командующего бригадой исправить не удавалось ввиду нехватки времени ${ }^{1}$. Тем самым он отдал распоряжение, прямо противоречащее Высочайше утвержденному "Положению об обучении пехоты", что свидетельствует об определённой самостоятельности командиров.

Разумеется, на ход подготовки пополнения для фронта обращал внимание и командующий округом. Уже 9 ноября 1914 г. занимавший тогда эту должность генерал от кавалерии Е. О. Шмит в приказе писал, что необходимо «С первых же дней поступления новобранцев в запасные батальоны выдать им винтовки и приступить к ознакомлению с ними, а также к обучению производства меткого выстрела и прохождению курса стрельбы, посвящая этому отделу обучения возможно более времени, с тем, чтобы на строевую выправку и изучение сведений, обязательных для рядового, затрачивались лишь время, ограниченное крайней необходимостью» ${ }^{2}$. Тем самым он частично повторял свою инструкцию еще 1910 г., в которой также требовал выдать молодым солдатам винтовки сразу по прибытии в часть ${ }^{3}$.

В разных батальонах различалось количество проведённых стрельб. Так, в 38-м Сибирском стрелковом запасном батальоне производили до трёх упражнений одиночной подготовительной стрельбы, в 36-м запасном батальоне - до шести ${ }^{4}$. В приказе по военному ведомству № 589 от 31-го октября 1915 г. военный министр А. А. Поливанов отмечал, что «за минувший год обнаружены весьма частые случаи отступления от установленной Наставлением для стрельбы 1914 года... последовательности и программы одиночной подготовки стрелка в запасных частях войск... не исполнялись весьма важные и существеннейшие отделы стрелковой подготовки, как то начальные упражнения стрельбы боевым патроном» 5 .

\footnotetext{
${ }^{1}$ РГВИА. Ф. 14160. Оп. 1. Д. 5. Л. 65.

2 Приказы по войскам Омского военного округа. 1914. №365.

${ }^{3}$ Фабрика Ю.А. Сибирь сражающаяся. Новониколаевск и новониколаевцы в Первой мировой войне $1914-$ 1918 гг. Том І. - Новосибирск: Сибирское книжное издательство, 2014. С. 182.

${ }^{4}$ РГВИА. Ф. 15172, Оп. Д.1. Л. 19.

5 Россия. Военное министерство. Приказы по Военному ведомству ... [по годам]. - СПб., 1853-1917.... за 1915 год. № 1-695: Алфавитный [и хронологический] указатель приказов по Военному ведомству и циркуляров Главного Штаба за 1915 год. - 1915. С. 760.
} 
Маршевые роты проверял и новый командующий округом, генерал-лейтенант Н. А. Сухомлинов. В том, что касается непосредственно подготовки рот, он обращал внимание на знание уставов, строевую подготовку, штыковой бой. Оценки выставлялись положительные, хотя высказывалось много замечаний ${ }^{1}$. Так, в 10-й роте 26-го Сибирского стрелкового запасного батальона нарекания вызвали занятия с винтовкой и скорость заряжания. В учебной команде 36-го Сибирского стрелкового запасного батальона было отмечено хорошее знание солдатами устава полевой службы; в 11-й роте того же батальона хорошее умение солдат маршировать и колоть штыком, а также грамотная работа с «инородцами», т.е. с татарами. Солдаты 7-й роты были названы развитыми и бодрыми, и отмечено, что они понимали цель идущей войны. Похвалы удостоились и маршевые роты от 19-го Сибирского стрелкового запасного батальона - отмечались их молодецкий вид и хорошее качество одежды ${ }^{2}$.

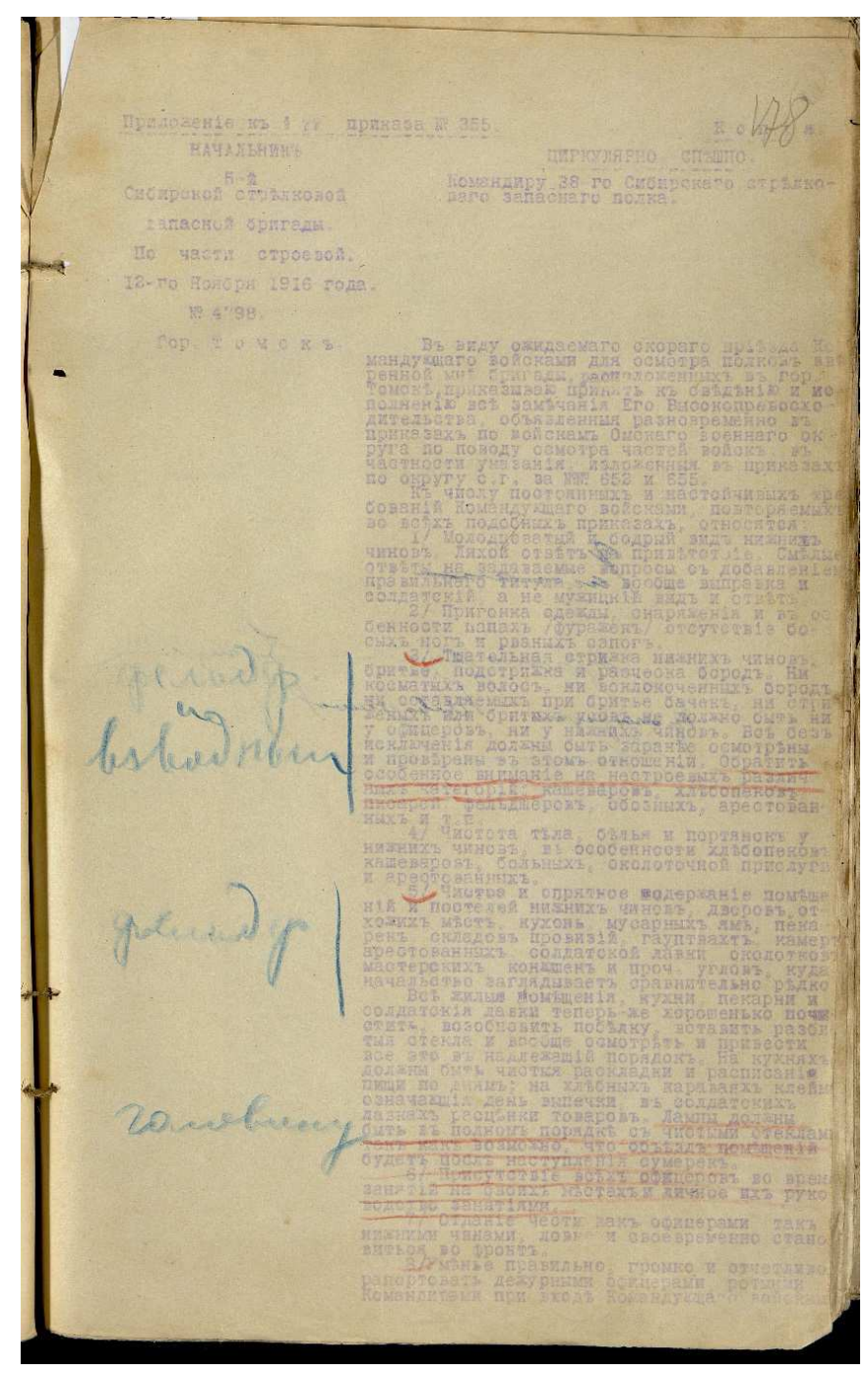

Инструкции командующего 5-й Сибирской стрелковой запасной бригадой по подготовке к визиту командующего войсками. ГАНО. Ф. Д-132. Оп.1. Д.18. Л. 178.

Основные приоритеты командующего округом при проверке подчинённых ему частей перечислены в послании командиру 38-го Сибирского стрелкового запасного полка от командующего 5-й Сибирской стрелковой запасной бригады за 12 ноября 1916 г., где

\footnotetext{
${ }^{1}$ ГАНО. Ф. Д-132. Оп. 1. Д. 1. Л. 137 об., 362; Д. 2. Л. 46

${ }^{2}$ ИАОО. Ф. 54. Оп. 1. Д. 107. Л. 119.
} 
давались инструкции по подготовке к прибытию командующего. Пояснялось, что для командующего округом важны:

а) молодцеватый и бодрый вид нижних чинов, стрижка, бритьё, уход за бородой;

б) пригонка и чистота одежды, наличие исправных сапог;

в) чистота помещений, наличие качественной пищи;

г) присутствие всех офицеров на занятиях;

д) своевременное отдание чести, становление во фронт, достаточно громкий рапорт;

е) готовность маршевых рот перед отправкой и на втором месяце обучения;

ж) представление всех офицеров, если не при осмотре, то позднее через командующего бригадой ${ }^{1}$.

Из приведенного перечня видно, что боевой подготовке командующий округом придавал не первостепенное значение. К прибытию командующего полки готовились заранее. В спешном порядке наводилась чистота, проверялись дежурные, обращалось внимание на отдельные элементы подготовки, вроде "колки чучела" и рассыпания в цепь, солдат стригли и брили (хотя в приказе по войскам Омского военного округа от 5 февраля 1916 г. командующий напомнил, что офицерам и нижним чинам запрещено брить усы) $)^{2}$ Таким образом, картина, которую видел по прибытии командующий, смотрелась выгоднее повседневной; с другой стороны, такая подготовка всё же улучшала ситуацию на некоторое время.

В конечном счете солдаты очередных рот пополнения проходили 2-3 проверки перед отправкой на фронт. Подытоживая всё вышесказанное, уместно привести замечания инспектора стрелковой части в войсках генерала от инфантерии С. Ф. Добротина от 10 июля 1916 г., приводившиеся в приказе по округу. Согласно этим замечаниям, «Одиночная подготовка нижних чинов почти во всех осмотренных запасных полках... в общем поставлена удовлетворительно. Есть полки, где подготовка людей хорошая. Все зависит от того, умелый и способный командир полка или нет» ${ }^{3}$. Генерал Добротин обращал также внимание на тот факт, что учебные программы для учебных команд имели значительные различия между собой (из-за того, что эти программы зачастую составлялись командирами полков); кроме того, в них не всегда указывалось, какие аспекты подготовки наиболее важны, а какими можно пренебречь ввиду краткосрочности обучения военного времени. Успевший лично принять участие в Первой мировой войне, генерал Добротин считал излишним обучение фехтованию в составе шеренги (хотя с удовлетворением отмечал, что обучение штыковому бою ведется хорошо), предлагал отменить заучивание баллистических данных полёта пули и обучение солдат постановке различных прицелов. Лишь походя и в общих выражениях он отмечал хороший уровень строевой подготовки в округе, гораздо подробнее высказываясь о стрельбе, боевой подготовке и содержании оружия. Однако, несмотря на все эти положения, генерал Добротин разделял типичное свойство драгомировской школы - пренебрежение к безопасности бойца. Ему принадлежит утверждение: "Солдат должен драться до последней возможности, оказывая самое отчаянное сопротивление, и не покидать своего места в цепи, будучи легко раненым, Также слишком большое значение придается применению стрелка к местности... Главное назначение стрелка - поразить врага огнем, чего он конечно не может достигнуть, скрывшись совершенно от взора противника" 4

В 1917 г. из-за изменений, которые армия претерпела в результате Февральской революции, в Омском военном округе значительно упало качество подготовки пополнений. Для повышения эффективности проверок их готовности 7 августа 1917 г. в приказе по

\footnotetext{
${ }^{1}$ ГАНО. Ф. Д-132. Оп. 1. Д. 18. Л. 178.

${ }^{2}$ ГАНО. Ф. Д-132. Оп. 1. Д. 9. Л. 53. Д. 19. Л. 50, 573; Приказы по войскам Омского военного округа. 1916. № 43.

${ }^{3}$ ГАНО. Ф. Д-132. Оп. 1. Д. 12. Л. 356-357.

4 Там же. Л. 357 об.
} 
гарнизону г. Томска была обозначена необходимость во внезапных проверках, о результатах которых нужно было доносить в штаб округа ${ }^{1}$. Такие проверки должны были проводиться трижды в неделю2 ${ }^{2} 6$ октября 1917 г., уже после прекращения активной подготовки очередных рот пополнения, командующий округом прапорщик П. Н. Половников, Военноокружной Комитет и военный совет осматривали полки округа. 28-й, 20-й, 37-й, 19-й Сибирские стрелковые запасные полки получили отметку "отлично", 36-й и 27-й - "хорошо", 26-й же вызвал нарекания - отмечалась недисциплинированность солдат, плохое качество их строевой подготовки. Командир полка был заменён, получившим после Февральской революции значительную власть демократическим организациям было рекомендовано обратить на указанные недостатки особое внимание ${ }^{3}$.

Подытоживая, следует помнить, что указания генералов и полковников, даже будучи объявлены личному составу отдельных батальонов, не всегда были способны напрямую и оперативно влиять на подготовку войск: уровень подготовки зависел во многом от личных качеств командиров рот. Но существенную роль играли и указания, получаемые от высших командиров. Каждый командующий из тех, чьи мнения по итогам смотров зафиксированы документально, имел свои приоритеты при оценке готовности очередных рот пополнения. Одни из них отдавали предпочтение своим излюбленным отделам подготовки, в то время как другие принимались бороться с проявлениями, по выражению П. А. Зайончковского, "плацпарадности". Некоторые из командующих следовали в каком-то виде концепции М. А. Драгомирова: генерал от инфантерии С. Ф. Добротин требовал учить "тому, что потребуется солдату в бою", генерал-лейтенант Н. А. Сухомлинов возвеличивал "солдатский дух", генерал-лейтенант Н. И. Тимченко-Рубан боролся за индивидуальное развитие солдата и сокращение курса строевой подготовки, а генерал от кавалерии Е. О. Шмит во главу угла ставил стрелковую подготовку, в чём ему следовал командир 38-го запасного полка подполковник Доброхотов. Особняком стоит командующий 5-й запасной бригадой полковник В. А. Бирон, уделявший огромное внимание полевой службе и правильному маневрированию в бою. Располагая в рамках действующих нормативных актов значительной свободой, эти офицеры имели возможность подстраивать установки, данные общими официальными положениями, под свои собственные представления.

Статья поступила в редакциюю 02.10.2018 г.

\section{Лuтература}

Бескровный Л. Г. Армия и флот России в начале XX в.: Очерки военно-экономического потенциала Институт истории АН СССР. М.: Наука, 1986. 238 с.

Зайончковский П.А. Самодержавие и русская армия на рубеже XIX-XX столетий. М.: Мысль, 1973. 355 с.

Керсновский А. А. История русской армии в 4-х томах. Т. 3. М.: Голос, 1994. 352 с.

Меннинг, Брюс У. Пуля и штык. Армия Российской империи, 1861-1914. М.: Модест Колеров, 2015. 424 с.

Свечин А. А. Эволюция военного искусства. Том ІІ. - М.-Л.: Военгиз, 1928. 619 с.

Строков А. А. Вооруженные силы и военное искусство в Первой мировой войне. М.: Воениздат, 1974. $611 \mathrm{c.}$

Фабрика Ю.А. Сибирь сражающаяся. Новониколаевск и новониколаевцы в Первой мировой войне 1914 - 1918 гг. Том I: - Новосибирск: Сибирское книжное издательство, 2014.

\footnotetext{
${ }^{1}$ ГАТО. Ф. 412. Оп. 2. Д. 9. Л. 404.

2 Приказы по войскам Омского военного округа. 1917. №520.

3 Приказы по войскам Омского военного округа. 1917. №671.
} 
Boff, Jonathan. Training to be soldier. [Электронный pecypc] URL: https://www.bl.uk/worldwar-one/articles/training-to-be-a-soldier (Дата обращения: 01.10.2018).

Knox, A. W. F. With the Russian Army 1914-1917, being chiefly extracts from the diary of a military attache. Vol. 1. London: Hutchinson \& co., 1921. 368 p.

Menning, Bruce W. Bayonets before Bullets. The Imperial Russian Army, 1861-1914. Indiana University Press, 2000. 334 p.

Pintner, Walter M. The Burden of Defense in Imperial Russia, 1725-1914. // The Russian Review, vol. 43, 1984, pp. 231-259.

Reforming the Tsar's Army: Military Innovation in Imperial Russia from Peter the Great to the Revolution. / ed. by David Schimmelpenninck van der Oye, Bruce W. Menning. Cambridge: Cambridge University Press, 2004. 376 p.

Stone, Norman. The Eastern Front, 1914-1917. London: Penguin, 1998. 348 p.

The Military History of Tsarist Russia. / ed. by Robin D. S. Higham, Frederick W Kagan. Palgrave, 2002. 266 p.

Transformation in Russian and Soviet Military History: Proceedings of the 12th Military Symposium United States Air Force Academy / ed. by Carl W. Reddel. United States Govt Printing Office, 1986. $405 \mathrm{p}$.

Travers, Tim. Could the Tanks of 1918 Have Been War-Winners for the British Expeditionary Force? // Journal of Contemporary History. Vol. 27, No. 3 (Jul., 1992), pp. 389-406.

Wildman, Allan K. The End of the Russian Imperial Army: The Old Army and the Soldiers' Revolt (March-April, 1917). Vol. 1. Princeton: Princeton University Press, 1980. 434 p.

Zabecki, David T. Military Developments of World War I. // 1914-1918 online International Encyclopedia of the First World War. / ed. by Ute Daniel, Peter Gatrell, Oliver Janz, Heather Jones, Jennifer Keene, Alan Kramer, and Bill Nasson, issued by Freie Universität Berlin, Berlin 2015-05-07. [Электронный pecypc] URL: https://encyclopedia.1914-1918-online.net/article/military_ developments_of_world_war_i (Дата обращения: 01.10.2018).

\section{References}

Beskrovny L. G. Armiya i flot Rossii v nachale XX v.: Ocherki voenno-ekonomicheskogo potentsiala [The Army and the Fleet of Russia at the beginning of the 20th century: the Essays of the Military-Economic Potential]. Institut istorii AN SSSR, M.: Nauka, 1986. 238 p.

Boff J. Training to be a soldier (London: British Library) available online at http://www.bl.uk/world-war-one/articles/training-to-be-a-soldier (Accessed: 01.10.2018).

Fabrika Y.A. Sibir srazhayuschayasya. Novonikolaevsk i novonikolaevtsy v Pervoy mirovoy voyne 1914 - 1918 [The fighting Siberia. Novonikolayevsk and its inhabitants in the First World War 1914 - 1918]. Vol. I. Novosibirsk: Sibirskoye knizhnoye izdatelstvo, 2014. 608 p.

Kersnovsky A.A. Istoriya russkoy armii v 4-kh tomakh [The History of the Russian Army in 4 volumes]. Vol. 3. M.: Golos, 1994. 352 p.

Knox, A. W. F. With the Russian Army 1914-1917, being chiefly extracts from the diary of a military attache. V. 1. London: Hutchinson \& co., 1921. 368 p.

Menning, Bruce W. Bayonets before Bullets. The Imperial Russian Army, 1861-1914. Indiana University Press, 2000. 334 p.

Menning, Bruce W. Pulya i shtyk. Armiya Rossiyskoy imperii, 1861-1914. M.: Modest Kolerov, 2015. $424 \mathrm{p}$.

Pintner, Walter M. The Burden of Defense in Imperial Russia, 1725-1914. // The Russian Review, vol. 43, 1984, pp. 231-259.

Reforming the Tsar's Army: Military Innovation in Imperial Russia from Peter the Great to the Revolution. / ed. by David Schimmelpenninck van der Oye, Bruce W. Menning. Cambridge: Cambridge University Press, 2004. 376 p.

Stone, Norman. The Eastern Front, 1914-1917. London: Penguin, 1998. 348 p. 
Strokov A.A. Vooruzhennye sily i voennoe iskusstvo v Pervoy mirovoy voyne [The Armed Forces and Military Art in the First World War]. M.: Voenizdat, 1974. 611 p.

Svechin A. A. Evolyutsiya voennogo iskusstva [The Evolution of military art]. Vol II. - M.-L.: Voengiz, 1928. 619 p.

The Military History of Tsarist Russia. / ed. by Robin D. S. Higham, Frederick W Kagan. Palgrave, 2002. 266 p.

Transformation in Russian and Soviet Military History: Proceedings of the 12th Military Symposium United States Air Force Academy / ed. by Carl W. Reddel. United States Govt Printing Office, 1986. $405 \mathrm{p}$.

Travers, Tim. Could the Tanks of 1918 Have Been War-Winners for the British Expeditionary Force? // Journal of Contemporary History. Vol. 27, No. 3 (Jul., 1992), pp. 389-406.

Wildman, Allan K. The End of the Russian Imperial Army: The Old Army and the Soldiers' Revolt (March-April, 1917). Vol. 1. Princeton: Princeton University Press, 1980. 434 p.

Zabecki, David T. Military Developments of World War I. // 1914-1918 online International Encyclopedia of the First World War. / ed. by Ute Daniel, Peter Gatrell, Oliver Janz, Heather Jones, Jennifer Keene, Alan Kramer, and Bill Nasson, issued by Freie Universität Berlin, Berlin 2015-05-07. [Электронный pecypc] URL: https:/encyclopedia.1914-1918-online.net/article/military_ developments_of_world_war_i(Accessed: 01.10.2018).

Zayonchkovsky P.A. Samoderzhavie i russkaya armiya na rubezhe XIX-XX stoletiy [Autocracy and the Russian army at the turn of the XIX-XX centuries]. M.: Mysl, 1973. 355 p. 